УДК: 78.01:781.7

DOI: https://doi.org/10.51209/platform.1.3.2021.246-258

Тетяна Борисівна КАБЛОВА, кандидат мистецтвознавства, доцент,

Київська муніципальна академія естрадного та циркового мистецтв,

Київ, Україна, e-mail: t.kablova@kmaecm.edu.ua,

ORCID: 0000-0002-6664-5288

\title{
ВОКАЛЬНО ЕСТРАДНЕ МИСТЕЦТВО В ДИСКУРСІ ФОРМУВАННЯ МУЗИЧНОГО ЕТОСУ КУЛЬТУРИ
}

\begin{abstract}
Анотація. Метою даної роботи $є$ розгляд концепції музичного етосу та обгрунтування ролі естрадного та вокального виконавства як явища для формування культурних цінностей найвищого рівня існування суспільства. Було проаналізовано значну кількість джерел, що дозволило визначити основні проблеми, що потребують вивчення, а саме вивчення естрадного мистецтва 3 позицій смислового навантаження щодо формування культурних цінностей. Методологія дослідження полягає у застосуванні порівняльного, історичного та логічного методів. Цей методологічний підхід дозволяє розкрити та проаналізувати певні погляди на українську популярну музику та іiі значення як культурний код швидкоплинних змін часу та значення цього виду мистецтва на шляху до позиції культурної цінності етосу. Встановлено, що культурний вектор вокальної та естрадної діяльності поширюється на антропологічний напрямок у контексті історичного та культурного сенсу існування суспільства, яке, в свою чергу, $є$ носієм як колективне несвідоме в процесі сприйняття дійсності. Це дозволяє вивчати естрадно-вокальне мистецтво як втілення цінностей короткого проміжку часу і як тенденцію до визначення вокально-естрадного мистецтва як соціокультурного явища в історичному континуумі, що впливає


на формування загальнолюдського музичного етосу. Близькість до соціальних подій людського життя, а також відповідність інтерактивному існуванню міжкультурної комунікації дозволяє нам стверджувати естрадно-вокальне мистецтво як спосіб виокремлення складової музичного етосу епохи. Визначено взаємозв'язок між соціальними та історичними факторами, які суттєво впливають на формування естрадно-вокального мистецтва, що дозволяє виокремити основні віяння та характерні погляди суспільства в короткий проміжок часу. Зазначено, що саме завдяки естрадно-вокальному мистецтву структурується певне підгрунтя для формування музичного етосу культури.

Ключові слова: естрадно-вокальне мистецтво, етос, цінності культури, музика, виконавство, суспільство, епоха

Вступ. У даний час все більшої гостроти набувають дискусії про місце музики в системі мистецтв, про творчий метод і художні принципи, перспективи музичної творчості в сучасному світі. По-різному осмислюється музика i як своєрідний культурний феномен. Одні автори вважають, що музика є специфічний вид пізнання і вираження світу, вона, за словами Т. Адорно, виписує сейсмограму дійсності, інші вважають, що музика створює ілюзорний світ, який не має ніякого відношення до реальності, що музика, особливо сучасна, відсторонюється в особливу галузь від емпіричної дійсності, від будь-яких слідів реального в музичному вираженні до такої міри, що здається, ніби вона не має нічого спільного ні з яким людським змістом. Серед контекстуальної експлікації музичного мистецтва, особливої уваги заслуговує вокальноестрадне виконавство. Саме естрадне виконавство потребує сьогодні не тільки вивчення як соціально-культурної складової суспільства, а й розгляду своїх складових на рівні виконавців, композиторів, а також інших складових побуту естрадновиконавського вектору.

Постановка проблеми. Музика постає як засіб викриття сутності буття. Саме звук несе в собі втілення матеріального та 
ідеального та відображає вібрацію життя. Музика відображає творящу силу Космосу, вона є життя в його різноманітності та організації хаосу. Метафізична сила музики проявляється у вигляді музичного принципу картини сутності Світобуття та іï мистецького втілення в музичних формах та об'єктах. «Музичне, 3 одного боку, космічне, 3 іншого - суб'єктивне: музичний космос, але музична і людська душа» $[1$, с. 6]. Тобто музика в своїх аналогах, які звучать, поєднує ірраціональність хаосу i формотворчість цілісності i можливість вищої системності гармонії. Звернення до таких можливостей музичного мистецтва знайшли виявлення в понятті музичного етосу - звернення до сутності музичного буття відповідно до культурно-історичного континууму, де викривається еволюція ціннісних орієнтирів людства в умовах нескінченного космосу. «У мистецтві етос $є$ його духовним стрижнем, моральнопсихологічною платформою, на якій вибудовується образноестетична тканина твору» [2, с.32]. Але, якщо ми говоримо про естрадне виконавство, яке існує як швидкоплинна миттєвість, як відповідь на події теперішнього часу, то ставлення до поняття етосу потребує глибшого вивчення.

Аналіз останніх досліджень і публікацій. Для вивчення зазначеного питання слід звернутися до дослідників, чиї праці знаходять в урочищі кросаналітичних підходів до вивчення музики як невід'ємної складової культури, духовного та соціального буття особистості, до вивчення етосу як духу епохи. Такі дослідження складають основу філософської думки від античності, Середньовіччя (Платон, Піфагор, Аристотель, Боецій та ін.), потім звернення до музики як дзеркала епохи у працях Р. Вагнера, Ф. Ніцше, А. Шопенгауера, О. Шпенглера та гібридних працях сучасних дослідників (С. Анчел, В. Личковах, Ю. Шабанова), що існують на стику наук та визначають культурологічний вектор музичного виконавства, що трактовано в антропологічному напрямку історико-культурного простору існування конкретного соціуму, який, у свою чергу, є носієм колективного несвідомого в процесі сприйняття музичного мистецтва. Також суттєвим внеском для розгляду саме 248 
естрадного виконавства та його співвіднесення 3 етосом культури стануть праці, присвячені вокально-виконавській творчості в контексті культури (В. Антонюк, А. Арутюнова, Н. Дрожжина, І. Ісаєва, О. Колубаєв, М. Мозговий, М. Муратов).

Мета статті - охарактеризувати поняття музичного етосу епохи як відбитку соціально-духовного буття особистості, розглянути вокально-естрадну культуру в контексті поняття музичного етосу епохи.

Виклад основного матеріалу. Поняття етосу сформувалося в епоху античності (з грецьк. - звичай, характер). У різноманітних тлумачних словниках він визначається як сукупність стійких рис індивіда, що $\epsilon$ незмінними й виявляються у характері. Французький естетик М. Дюфренн вказує на те, що Платон позначив етосом чуттєвість вищої форми, яка виникає як реакція на художній твір та перегукується з традицією морального очищення за допомогою етосу музики, що широко використовувалася в Піфагорейській школі (гармонія - музика сфер на інтервалах). Піфагорійці вірили, що все, що існує, має голос, і все, що створено, вічно співає хвалу Творцю. Людина не в змозі утримати в собі ці мелодії, тому що душа заплуталася в ілюзії матеріального існування. Коли вона звільнить себе від тягаря нижчого світу, 3 його обмеженим чуттєвим сприйняттям, музика сфер знову зазвучить. Арістотель визначав етос як динамічну сутність людської душі, яка може бути тільки при гармонійному становленні особистості, а музика в цьому виступає як те, що за допомогою засобів музичної виразності показує духовні якості людини та космосу, відображає реальну гармонійну дійсність [3]. Тобто, саме метафізичність міститься в етосі музиці, що звучить та існує як духовний субстрат, духовна складова у музичній матеріальній формі. Ця метафізична сутність закладена в безперервному розвитку матерії, а існуюча музична форма моделює актуальний час, актуальну епоху. Виникає інтеграція людського та космічного, викривається справжній сенс людського існування. На підгрунті античного спадку формуються безпосередньо й погляди Ф. Ніцше, який 
підкреслює унікальну роль музики в культуротворчому бутті людини: «Музика - це незалежне мистецтво, яке стоїть одноосібно від усіх інших мистецтв, вона не пропонує, подібно останнім, зліпки 3 феноменального (в кантівському розумінні) світу, а говорить мовою самого буття безпосередньо з безодні» [8, с.241]. Тобто у музиці немає явного осмислення знайденої істини, бо сама істина має специфічний вид. Минаючи свідомість, де існують а-priori закладені ілюзії людського світосприйняття, музика, яка несе ядро, де поєднані історичні умови існування людства та сьогоденні реалії буття, прямує до підсвідомості, примушує нас «бачити більше і глибше». У своїх міркуваннях про дух культури Ніцше пов'язує музичний етос із тим, що музика може ставати таким відображенням реальності, де імпліцитно присутня гармонія аполлонічного і діонісійського начал. Саме в етосі музики людство відображається естетично, але не бачить себе спотвореним у реальному відображенні буття. Саме через музику, найабстрактнішу естетичну модель інформації, образно-емоційно виражену за допомогою звуків, Ніцше стверджує апріорне відображення світової гармонії. Так само етос музики знаходить вираження у Шопенгауера. Музика постає як універсальна логічна схема у мовно-інтонаційних алгоритмих, які за природою та етосом волі тотожні Космосу й змінюються трансмірно з гармонією Всесвіту, світової «волі до життя». Артур Шопенгауер доходить висновку, що ступінь метафізичної незалежності етосу музики від «світу явищ» робить можливим іiі існування навіть у тому випадку, якби цього «поцейбічного» світу зовсім не було [7, с.356]. Німецький філософ вбачає «паралелізм» музики та світу в адекватному відображенні волі, підкреслюючи ізоморфність в їх гармонійноструктурній організації. Історію людства О. Шпенглер подає як «сукупність величезних життєвих шляхів», як «драму, в якій бере участь низка потужних культур». У такому контексті культура постає майже однорідною субстанцією, де внутрішня єдність форм мислення і творчості поєднується з єдністю форм соціального, духовного релігійного та мистецького життя [9, с.101-128]. Ця єдністю визначається «душею», «прасимволом» 
культури як ідеєю існування, що акумулює незаперечні для епохи цінності та надає їй динаміки розвитку. Цей специфічний «прасимвол» лежить в основі кожної культури. Він є реальним духом епохи, в якому закодована існуюча культура. Тобто, за О. Шпенглером, це ключ для розуміння морфології даної культури, те, що дозволяе зрозуміти унікальність кожної культури, яка забезпечується своєрідністю іiі душі. За своєю сутністю ці праці стали основними для наступних дослідників музичного етосу. С. Анчел, Дж. Беккон, О. Блок, Р. Вагнер - до сьогодення ці дослідники стверджували музику як певний універсальний код епохи. Інакше кажучи, етос як втілення такого маркера епохи, який відображається в творах, сучасних цій епосі та буде необхідним для епохи майбутньої, тобто притаманний як історії в цілому, так і окремому індивіду. Сва Анчел стверджує етос як певний універсальний елемент, де поєднується історична діяльність та творча самосвідомість яка отримує прояв у музичних творах. Тобто формує те, що В. Личковах охарактеризував як творчість індивіда, яка просякається духом історизму, сама здійснює загальнолюдський «зв'язок часів» [2, с.9-11]. У такому контексті музичний твір стає парадигмою чуття, де існуючий дух музики, тобто музичний етос несе в собі не дискурсивний потенціал рефлексивної реакції, а несвідомий емоційний вираз внутрішньої сутності світу, вольової квінтесенції життя.

Музика відіграє в житті сучасної людини, без перебільшення, колосальну роль. На одному полюсі академічна музика, на іншому - масова культура. На стику цих двох «протилежностей» - твори композиторів «третьої течії», спроба з'єднання елементів і технік т. зв. «серйозної» і «легкої» музики. У сучасному «суспільстві споживання» на одному полюсі виявляється «масова культура», тобто культура як предмет споживання, 3 естетикою розважальності, іншим полюсом $є$ елітарна академічна складова. Естрадне вокальне виконавство за своєю сутністю передбачає вербальне, текстове наповнення, що забезпечує полегшення сприйняття образів, 
закладених в музиці та /або тих, що є соціально-значущими в умовах свого часу.

Однією з задач в сфері естрадно-вокального виконавства стає висвітлення соціокультурної семантики існуючого покоління. Іншими словами, формування взаємодії між жанровою природою цієї галузі та емоційно-чуттєвими факторами людської культури. Йдеться про те, що естетичні параметри взаємодії масового естрадно-музичного мистецтва 3 реципієнтом, споживачем вокального-естрадного продукту грунтуються на культурологічно-соціологічних чинниках, які спрямовані на зовнішнє оформлення номеру, на стиль поведінки виконавця. На цьому підгрунті постать співака стає соціальнозначущою фігурою, а його виконавство визначається вже не тільки як творчий акт, а як певний вплив на формування емоційного стану, як трансляція соціальних змін у суспільстві. Це дозволяє провести паралелі між вокальним виконанням у давнину в магічних культах, де співак виявляється «корифеєм» (провідником) між світом людей і світом духів (наприклад, Орфей у давньогрецькій міфологіi).

Це $є$ втілення в певних глобалізаційних універсальних моментах, серед яких емоційно-інтуїтивне втілюється на виражальні, пізнавальні та евристичні можливості музичного мистецтва, але не на загально-історичному рівні, а в більш малих пропорціях. Слід зазначити, що сьогодні відбувається складний період дух раціоналізму в культурі змінився духом утилітаризму та прагматизму [4, с.121]. При цьому спостерігається шалений зріст пошуку своєї самобутності, першочергове це відбувається саме через музичне мистецтво. Естрадно-вокальне виконавство як найдоступншіе людині через свою лапідарну манеру викладення здатне забезпечити ту єдність із соціумом, яка дозволяє ідентифікувати себе як частину певного культурно-історичного прошарку. Сьогодні ми спостерігаємо за чіткими визначеннями культур: музика 1980-х pp., музика 1990-х рр. і необхідно наголосити, що йдеться саме про естрадно-вокальну музику. Проведені дослідження (соціальні опитування, бесіди, анкетування) різних за віком та 
гендерної приналежності індивідуумів показали, що першочергово при згадці років виникає асоціація з політичною ситуацією та естрадно-вокальною культурою. Тут слід акцентувати увагу, що в музичному прояві співіснують нематеріальне, часове та зафіксоване у конкретній культурі формотворення, кристалічне, що імпліцитно окреслює основні етапи дискурсу соціуму: «Одноразове поєднання несумісного вкорінює в музиці пї максимальну граничність у вигляді автентичного відображення Абсолюту в своєму первинному самопізнанні» $[6$, с.30].

Якщо в академічному мистецтві музики закладено емоційні образи того, що в принципі не може бути точним описом, точно позначено i виходить iз конкретно-заданих величин, то естрадна музика здатна проілюструвати та передати всю подієвість, образи, іманентні тому чи іншому предметові або події риси, навіть швидкоплинного характеру.

Висновки. Отже, якщо ми говоримо про музичний етос як метафізичну сутність музики, де існує логічність, упорядкованість мислення та евристичність подання, то можна стверджувати, що музична культура естради виконує значення фонового простору, де й виокремлюються загально-людські цінності. На цьому тлі музичний етос відображає культурну цивілізацію суспільства, де закладено історичний ступень розвитку людства, його індустріальні наміри й можливості; першочергове, те, що народжується в середині цього суспільства, саме те, що й відображає власне естрадна музика. Можна стверджувати, що естрадно-вокальне мистецтво через його власний досвід, через історію соціально-естетичної практики як продукування сучасних образів, через рецепцію та комунікацію лежить в основі музичного етосу епохи. Вивчення естрадно-вокального мистецтва є вельми потужною базою для осягнення соціального устрою людства, вподобань, потреб та розвитку індивідуумів, що має в собі частину мистецького досвіду масового характеру негативного плану, але яке, безсумнівно, потрібно саме для формування враження загального культурного тла. 


\section{Література}

1. Давыдов Ю. Освальд Шпенглер и судьба романтического мировоззрения. Проблемы романтизма. сб. 2. Москва: Искусство, 1971. 304 с.

2. Личковах В. Дивосад культури: Вибрані статті 3 естетики, культурології, філософії мистецтва. Чернігів: Деснянська правда, 2006. 160 с.

3. Лосев А. Очерки античного символизма и мифологии. Москва: Мысль, 1993. 960 с.

4. Самая Т. Вокальне мистецтво естради як чинник культурного життя України другої половини XX - початку XXI століття: дис. ... на здобуття наук. тупеня канд. мистецтвознав.. Київ, 2017. 199 с.

5. Сапожнік О. Популярна естрадна музика в Україні: історичний екскурс. Мистецтво та освіта. 2003. № 4. Сс. 11-13; 2004. № 1. Cc. 19-20.

6. Шабанова Ю.Метафизическое пространство музыки. Вісник Дніпропетровського університету. 2010. №9/2. Сс. 28-33. 7. Шопенгауэр А. Мир как воля и представление. Минск: ООО «Попурри», 1999. Т.2.832 с.

8. Baugh H. Nietzsche and his music. Musical Quarterly. London, 1926. № 12. Apr. Pp. 238-247.

9. Dahlhaus C. Systematiche Musikwissenschaft. Wiesbaden: Akademische Verlagsgesellschaft Athenaion, 1982. 380 p. 
Татьяна Борисовна КАБЛОВА, кандидат искусствоведения, доцент, Киевская муниципальная академия эстрадного и циркового искусств, Киев, Украина, e-mail: t.kablova@kmaecm.edu.ua, ORCID: 0000-0002-6664-5288

\section{ВОКАЛЬНО-ЭСТРАДНОЕ ИСКУССТВО В ДИСКУРСЕ ФОРМИРОВАНИЯ МУЗЫКАЛЬНОГО ЭТОСА КУЛЬТУРЫ}

Аннотация. Целью данной работы является рассмотрение концепции музыкального этоса и обоснование роли эстрадно-вокального исполнительства как явления для формирования культурных ценностей высокого уровня существования общества. Проанализировано значительное количество источников, что позволило определить основные проблемы, требующие изучения, а именно - изучение эстрадного искусства с позиций смысловой нагрузки по формированию культурных ценностей. Методология исследования заключается в применении сравнительного, исторического и логического методов. Такою симбеоз в методологическом подходе позволяет раскрыть и проанализировать определенные взгляды на украинскую популярную музыку и ее значение как культурный код быстрых изменений времени и значение этого вида искусства на пути к позиции культурной ценности этоса. Установлено, что культурный вектор вокальной и эстрадной деятельности распространяется на антропологическое направление в контексте исторического и культурного смысла существования общества, которое, в свою очередь, является носителем коллективного бессознательного в процессе восприятия действительности. Это позволяет нам изучать эстрадновокальное искусство как воплощение ценностей короткого промежутка времени и как тенденцию к определению вокально- 
эстрадного искусства как социокультурного явления в историческом континууме, влияющем на формирование общечеловеческого музыкального этоса. Близость к социальным событиям человеческой жизни, а также соответствие интерактивному существованию межкультурной коммуникации позволяет нам утверждать эстрадно-вокальное искусство, как способ выделения составляющей музыкального этоса эпохи. Определена взаимосвязь между социальными и историческими факторами, которые существенно влияют на формирование эстрадно-вокального искусства, позволяющего выделить основные веяния и характерные взгляды общества в короткий промежуток времени. Отмечено, что именно благодаря эстрадно-вокальному искусству структурируется определенные основания для формирования музыкального этоса культуры.

Ключевые слова: эстрадно-вокальное искусство, этос, ценности культуры, музыка, исполнительство, общество, эпоха

\section{Tetiana B. KABLOVA,}

PhD in Arts, Associate Professor,

Kyiv Municipal Academy of Circus and Performing Arts,

Kyiv, Ukraine, e-mail: t.kablova@kmaecm.edu.ua,

ORCID: 0000-0002-6664-5288

\section{VOCAL POP ART IN THE DISCOURSE OF FORMING OF THE MUSICAL ETHOS OF CULTURE}

Abstract. The purpose of this work is to consider the concept of musical ethos, and justify the role of pop and vocal performance as a phenomenon for the formation of cultural values of the highest level of existence of society. A significant number of sources were been analyzed, which allowed to identify the main problems that need to be studied, namely the study of pop art from the standpoint of semantic load in relation to the formation of cultural values. The research methodology is to apply comparative, historical and logical methods. This methodological approach allows 
to reveal and analyze certain views on Ukrainian popular music and its significance as a cultural code of fleeting time changes and significance this kind of art in the way of standpoint of ethos cultural value. It is established that the cultural vector of vocal and pop activity extends to the anthropological direction in the context of the historical and cultural meaning of the existence of society, which, in turn, is the carrier as the collective unconscious in the process of perception of reality. This allows us to study pop art as the embodiment of values of a short period of time and as a tendency to define vocal art as a socio-cultural phenomenon in the historical continuum, which influences the formation of universal musical ethos. Proximity to the social events of human life, as well as compliance with the interactive existence of intercultural communication allows us to assert the pop and vocal art as a way to distinguish a component of the musical ethos of the era. This paper attempts to identify the relationship between social and historical factors that make up the value layer of culture and the formation of pop music as a phenomenon that can universalize the values of culture. It can be argued that today pop vocal music reflects the main characteristics of the era and creates universal images that are inherent in the cultural values of society. The materials of the article can be used in the study of pop music in the context of the historical development of culture.

Key words: pop and vocal art, ethos, cultural values, music, performance, society, epoch

\section{References}

1. Davydov, Y. (1971). Osval'd Shpenhler s sud'ba romantycheskogo mirovizzreniya. Problemy romantizma. [Oswald Spengler and lots of romantic philosophy. Problems of Romanticism] sb. 2. Moscow: Iskusstvo [in Russian].

2. Lychkovah, V. (2006). Dyvosad kul'tury: Vybrani statti z estetyky, kul'turolohiyi, filosofiyi mystetstva. [Divosad culture: Selected articles on aesthetics, culture, philosophy of art]. Chernigov: Desnyanska truth [in Ukrainian]. 
3. Losev, A. (1993). Ocherki antichnoho simvolizma i mifologii. [Essays on ancient symbolism and mythology]. Moscow: Mysl [in Russian].

4. Samaia, T. (2017). Vokalne mystetstvo estrady yak chynnyk kulturnoho zhyttia Ukrayiny druhoyi polovyny XX - pochatku XXI stolittia [Vocal art of pop as a factor in the cultural life of Ukraine in the second half of the XX - early XXI century]: dys. ... na zfobuttya nauk. stupenya kand. mystetstvoznav. Kyiv [in Ukrainian].

5. Sapozhnik, O. (2003; 2004). Populyarna estradna muzyka v Ukrayini: istor. Ekskurs [Popular variety music in Ukraine: a historical excursion]. Mystetstvo ta osvita, 4, 11-13; 1. 19-20 [in Ukrainian].

6. Shabanova, YU. (2010). Metafizychne prostir muzyky. [Metaphysical space of music]. Visnyk Dnipropetrovs'kogo Universitetu, 9 / 2, 28-33 [in Ukrainian].

7. Shopenhauér, A. (1999). Mir kak volya i predstavlenie [The world as will and representation]. Minsk: TOV "Popurry", 2 [in Russian].

8. Baugh, H. (1926). Nietzsche and his music. Musical Quarterly. London,12, Apr., 238-247 [in English].

9. Dahlhaus, C. (1982). Systematiche Musikwissenschaft. Wiesbaden: Akademische Verlagsgesellschaft Athenaion [in German]. 